\title{
Peran Interaksi Simbolik dalam Perencanaan Komunikasi Pemasaran di Era Pandemi

\author{
(Studi Kasus Kopi Lain Hati Sukasari Bogor)
}

\author{
Alfari Josita, Muhammad Adi Pribadi \\ deboraalfari@gmail.com, adip@fikom.untar.ac.id
}

Fakultas Ilmu Komunikasi Universitas Tarumanagara

\begin{abstract}
The purpose of marketing is to introduce a product and increase sales. Another Coffee Hati is one of the franchise business fields that has opened four hundred branches in Indonesia, one of which is Kopi Hati Hati Sukasari Bogor. Managing a business during a pandemic is an interesting thing, where cafe owners must of course have ways to attract consumers and also make consumers still feel safe when buying products at the venue. In running its business, of course Kopi Hati Hati Sukasari Bogor has a strategy that can make its business grow. Of course the strategy includes a review, regulations, promotions, and its target market and before implementing the strategy there are also several things that have been considered such as a first review. In this research has a very important role. This research uses a qualitative methodology with a case study method. Collecting data in this method by means of in-depth interviews, documentation, archival records and participant observation. In this research, there is an interaction that symbolizes symbols such as regulations and the use of language in daily activities at Kopi Hati Hati Sukasari Bogor.
\end{abstract}

Keywords: case studies, coffee franchises, marketing communications, symbolic interactionism

\begin{abstract}
Abstrak
Tujuan sebuah pemasaran adalah memperkenalkan suatu produk serta meningkatkan penjualannya. Kopi Lain Hati merupakan salah satu bidang usaha franchise yang telah membuka empat ratus cabang di Indonesia, salah satunya adalah Kopi Lain Hati Sukasari Bogor. Mengelola bisnis di masa pandemi merupakan hal yang menarik, dimana pemilik café tentunya harus mempunyai cara bagaimana menarik konsumen juga membuat konsumen tetap merasa aman ketika membeli produk di tempat tersebut. Dalam menjalankan bisnis nya tentu Kopi Lain Hati Sukasari Bogor mempunyai strategi yang dapat membuat bisnisnya semakin berkembang. Tentunya strategi tersebut meliputi peninjauan, peraturan, promosi, serta target marketnya dan sebelum menjalankan strategi tersebut juga ada beberapa hal yang telah diperhatikan seperti peninjauan terlebih dahulu. Dalam penelitian ini memiliki peran yang sangat penting. Penelitian ini menggunakan metodologi kualitatif dengan metode studi kasus. Pengumpulan data dalam metode ini dengan cara wawancara mendalam, dokumentasi, rekaman arsip dan observasi partisipan. Dalam penelitian ini terjadi adanya interaksi yang melambangkan simbol-simbol seperti peraturan dan adanya penggunaan bahasa dalam kegiatan sehati-hari di Kopi Lain Hati Sukasari Bogor.
\end{abstract}

Kata Kunci: franchise kopi, interaksi simbolik, komunikasi pemasaran, studi kasus 


\section{Pendahuluan}

Komunikasi pemasaran merupakan hal yang sangat penting dalam dunia bisnis, karena dengan adanya komunikasi pemasaran yang baik tentu akan membawa dampak yang baik untuk bisnis yang dijalankan. Komunikasi pemasaran merupakan bentuk menjalin hubungan dengan konsumen. Komunikasi Pemasaran yang sudah banyak diketahui adalah beriklan seperti yang sudah sering kita lihat banyak dari pebisnis yang memasarkan barang dagangannya melalui beriklan. Saat ini bisnis franchise merupakan salah satu bisnis menjanjikan yang banyak digemari oleh masyarakat dari semua kalangan khususnya anak-anak muda. Banyaknya bisnis franchise yang saat ini berkembang di Indonesia membuat persaingan menjadi begitu ketat karena dari bisnis yang dijalankan tersebut memiliki kelebihan dan kekurangannya tersendiri, salah satunya adalah bisnis kopi.

Kopi Lain Hati merupakan kopi yang saat ini sudah mulai diketahui banyak masyarakat, namun tidak cukup sampai disini tentunya dengan banyaknya gerai kopi lain yang sudah terlebih dahulu mempunyai nama besar membuat Kopi Lain Hati harus lebih mempunyai ekstra strategi demi membangun citra mereknya di kalangan masyarakat Indonesia khususnya. Salah satu bentuk komunikasi pemasaran yang dilakukan Kopi Lain Hati yaitu dengan memberikan tayangan video mini series yang berdurasi satu menit di setiap videonya.

Dalam menjalankan bisnisnya, Kopi Lain Hati menyadari bahwa banyak tantangan yang harus dihadapi ketika bisnis franchise ini mempunyai beberapa kompetitor. Setiap kopi yang ada di daftar menu memiliki keunikan dari namanya yang membuat calon konsumen akan dengan mudah mengingatnya. Nama - nama kopi tersebut di buat dengan gaya bahasa kaum milenial saat ini sesuai dengan perkembangan zaman yang ada di Indonesia. Dalam komunikasi pemasaran, Kopi Lain Hati mini series menjadi salah satu strategi yang di keluarkan oleh Kopi Lain Hati untuk berinteraksi dengan calon konsumennya di media sosial Instagram. Dan sebagai bentuk apresiasi terhadap para penonton yang telat ikut berkomentar dalam video mini series, maka Kopi Lain Hati memberikan hadiah minuman gratis.

Hal ini merupakan bentuk dari strategi pemasaran yang dijalankan Kopi Lain Hati melalui video mini seriesnya agar semakin banyak lagi masyarakat yang mengetahui kopi tersebut. Di samping itu pula dengan adanya video mini series dapat mengetahui berapa banyak masyarakat yang ingin mencoba sensasi rasa dari Kopi Lain Hati dengan menikmati hadiah kopi gratis yang diberikan langsung oleh Kopi Lain Hati. Dengan adanya penelitian ini, peneliti akan mencari tahu bagaimana proses interaksi simbolik dalam perencanaan komunikasi pemasaran di Kopi Lain Hati yang mampu bersaing dengan berbagai gerai-gerai kopi yang sudah terlebih dahulu ada di bandingkan dengan Kopi Lain Hati dan membuka banyak cabang di setiap kota besar yang ada di Indonesia.

Teori interaksi simbolik mendeskripsikan bagaimana terjadinya proses antara simbol dan interaksi. Untuk itu teori ini dapat disebut sebagai bentuk pemahaman dengan simbol-simbol yang ada saat individu berinteraksi dengan individu lainnya. Simbol tersebut terjadi karena adanya sebuah kesepahaman makna simbol tersebut. Teori interaksi simbolik berkeyakinan bahwa individu dapat membentuk makna melalui proses komunikasi. Pada saat makna tersebut telah terbentuk, tentunya proses komunikasi akan berjalan dengan sangat baik. Karena dari makna tersebut membuat kesalahpahaman menjadi dapat diatasi. 
Mead menjabarkan dalam sebuah buku yang berjudul Mind, Self, and Society (Pikiran, Diri, dan Masyarakat) menyebutkan tiga konsep penting dari interaksi simbolik yang tentunya saling berhubungan. Berikut ini merupakan penjelasan mengenai pikiran, diri, dan masyarakat berdasarkan buku West \& Turner, 2008. Menurut Kotler \& Keller (2008) Komunikasi pemasaran adalah sebuah proses bagaimana saling menguntungkan antara penjual dan pembeli. Dua sasaran pemasaran adalah menarik individu agar menjadi pelanggan dengan menjanjikan dari keunggulan produk, serta menjaga pelanggan yang sudah ada dengan terus memberikan yang terbaik untuk pelanggan tersebut.

Tujuan Komunikasi menurut Larry Percy \& Richard Elliot (20012) adalah suatu strategi komunikasi yang membangun hubungan untuk saling menguntungkan. Dalam menjalankan suatu komunikasi pemasaran akan lebih baik apabila hal tersebut didasarkan oleh perencanaan yang tepat langsung ke sasaran. Tujuan komunikasi dibagi menjadi dua yaitu tujuan bisnis dan strategi (tujuan komunikasi, target market, kompetitor, tema komunikasi, saluran komunikasi).

\section{Metode Penelitian}

Dalam penelitian ini peneliti menggunakan metode penelitian kualitatif. Di dalam buku Metodologi Penelitian Kualitatif, menurut Moleong bahwa penelitian kualitatif dapat didefinisikan bahwa penelitian kualitatif adalah sebuah penelitian yang bertujuan untuk lebih mengerti fenomena yang dialami oleh subjek penelitian yang di dalamnya melibatkan perilaku, persepsi, motivasi, tindakan dan setelah itu di deskripsikan dalam bentuk kata-kata pada konteks tertentu dengan menggunakan metode alamiah.

Dalam penelitian studi kasus terdapat tiga tipe yaitu studi kasus eksplantoris, eksploratoris, dan deskriptif. Studi kasus yang digunakan oleh peneliti adalah eksploratoris. Secara umum, studi kasus sangat cocok apabila dikaitkan degan penelitian yang pertanyaan nya bersifat how atau why. Dalam praktknya peneliti studi kasus perlu lebih memusatkan perhatian nya pada pendesainan dan penyelenggaraan nya agar dapat menangani kritik-kritik tertentu terhadap tipe pilihannya (Yin, 2013).

Beberapa komponen-komponen desain penelitian yang juga sangat penting pertama pertanyaan penelitian, pertanyaannya akan bervariasi tetapi lebih disarankan agar bentuk pertanyaan tersebut seperti "siapa", "apa", "dimana", "bagaimana", dan "mengapa". Strategi studi kasus lebih cocok untuk pertanyaan dengan "bagaimana" dan "mengapa" (Yin, 2013). Subjek dalam penelitian ini adalah narasumber atau informan yang dapat memberikan informasi terhadap masalah yang diteliti oleh peneliti. Subjek tersebut bisa sebagai individu/komunitas/organisasi yang di dalam dirinya melekat objek penelitian ini. Narasumber atau informan tersebut harus memberikan informasi yang jelas dan akurat kepada peneliti agar peneliti dapat menemukan hasil penelitiannya.

Desain penelitian diperlukan dalam pendekatan umum studi kasus. Dalam penelitian ini menggunakan metode pengumpulan data observasi, wawancara mendalam, dokumentasi, dan rekaman arsip. Teknik ini dilakukan untuk menjadi penguat atau membuktikan bahwa penelitian ini benar-benar merupakan penelitian ilmiah juga untuk menguji data yang sudah diperoleh agar data tersebut dalam penelitian kualitatif dapat dipertanggungjawabkan.

Peneliti melakukan wawancara dengan para informan untuk dikumpulkan datanya. Kemudian peneliti akan membuat penafsiran atas data yang diperoleh dari 
hasil wawancara. Hasil penafsiran peneliti nantinya akan dikembalikan lagi kepada informan untuk memastikan penafsiran ini benar adanya sesuai dengan pengalaman para informan.

\section{Hasil Temuan dan Diskusi}

Kopi Lain Hati merupakan jenis usaha franchise yang memiliki keunikan tersendiri dalam menghadirkan menu-menu kopinya, hal tersebut dapat dilihat dari nama-nama di dalam buku menu nya. Dan lagi kopi Lain Hati juga selain menjual minuman, mereka juga merupakan franchise yang menjual berbagai macam makanan santai dan juga makanan berat, hal ini tergantung dari kebijakan masing-masing pemilik setiap cabang di kopi Lain Hati.

Dalam memasarkan produknya, kopi Lain Hati menerapkan strategi berupa video mini series yang berdurasi satu menit di setiap video nya sebagai sarana pemasaran dan membuat quiz yang berhadiahkan kopi sebagai bentuk apresiasi dari kopi Lain Hati kepada siapa saja yang ikut serta dalam quiz tersebut. Berdasarkan data yang telah diperoleh saat penyelesaian tugas akhir ini kopi Lain Hati menjadi bagian dari konsep Generelized Others yang dijelaskan oleh Mead. Sebagaimana diberlakukan nya peraturan baru (PSBB) dari pemerintah yang membuat kopi Lain Hati harus mengikuti aturan tersebut untuk meminimalisir rantai penyebaran covid- 19 .

Pembahasan ini adalah berdasarkan wawancara mendalam yang peneliti lakukan dengan kopi Lain Hati cabang Sukasari Bogor sangat erat kaitannya dengan teamwork pada proses pembentukan perencanaan komunikasi pemasaran yang disambungkan dengan teori terkait dalam penelitian ini adalah Teori Interaksi Simbolik dan Komunikasi Pemasaran.

\section{Pemilihan Merek dan Peninjauan}

Sebelum menjalankan usaha ini, tentu pemilik terlebih dahulu mencari tahu bagaimana bisnis yang sedang happening saat ini. Banyak pemikiran serta melalui proses yang cukup detail sampai akhirnya memutuskan untuk memilih usaha di bidang franchise kopi ini. Menurut penjelasan dari informan, bahwa dalam menjalankan bisnis ini beliau juga harus mempelajari bagaimana produknya serta variasi di dalam produknya. Dan juga menurut informan bahwa kopi Lain Hati memiliki bahasa-bahasa yang unik untuk digunakan sehingga bahasa tersebut dapat memudahkan kopi Lain Hati cepat diketahui oleh banyak masyarakat melalui namaya yang berbeda dengan gerai-gerai kopi lainnya.

Dalam hal ini sudah sangat jelas dapat disimpulkan bahwa seperti yang telah dijelaskan oleh Mead, bahwa Teori Interaksi Simbolik berkeyakinan bahwa individu dapat membentuk makna melalui proses komunikasi. Pada saat makna tersebut telah terbentuk tentunya proses komunikasi akan berjalan dengan sangat baik.

\section{Peraturan}

Aturan tentu dibuat untuk terciptanya sebuah perusahaan agar semakin maju dan berkembang, dengan adanya peraturan tentu akan membuat karyawan dan staff tidak bisa meremehkan pekerjaan nya. Seperti peraturan yang ada di kopi Lain Hati cabang Sukasari bahwa setiap aturan mempunyai sanksi tersendiri apabila dilanggar, Namun dalam bekerja sama degan semua karyawan yang ada di kopi Lain Hati cabang Sukasari pemilik tidak dapat seratus persen menjadi diri sendiri karena dalam 
menjalankan tugasnya sebagai pemilik tentu mempunyai banyak keterbatasan agar tidak terjadi hal-hal yang tidak diinginkan.

Hal ini mempunyai arti yang sama dengan yang telah dipaparkan oleh Mead mengenai hubungan antara individu dan masyarakat. Dimana hal tersebut memaparkan tentang bagaimana kaitan antara kebebasan individu dan batasan sosial. Berdasarkan dari hal tersebut dapat disimpulkan bahwa pada interaksi simbolik makna memiliki peran yang penting untuk perilaku manusia

\section{Promosi}

Promosi dalam kopi Lain Hati memiliki dua tipe. Promosi yang dilakukan secara serentak dari pusat, dan juga promosi yang diadakan sendiri oleh ketentuan setiap cabang. Dengan adanya promosi ini tentu dapat menarik perhatian konsumen para pecinta kopi. Kegiatan promosi yang dilakukan oleh masing-masing pemilik di setiap cabang merupakan salah satu bentuk pemasaran juga, yang dimana dalam hal tersebut sang owner ingin lebih banyak masyarakat Bogor mengetahui adanya kopi Lain Hati yang berada di cabang Sukasari. Seperti yang telah dijelaskan oleh informan satu, bahwa setiap promosi yang dilakukan oleh masing-masing pemilik setiap cabang juga telah mendapat persetujuan dari kantor pusat kopi Lain Hati.

\section{Strategi Pemasaran}

Secara luas pemasaran adalah proses sosial yang artinya dimana penjual mendapatkan apa yang mereka butuhkan melalui pertukaran nilai dengan orang lain. . Karena itu pemasaran dapat di definisikan sebagai bentuk proses dimana perusahaan menciptakan nilai yang baik untuk pelanggan serta menciptakan adanya hubungan baik jangka panjang dengan pelanggan yang bertujuan mendapatkan nilai yang bagus dari pelanggan sebagai bentuk apresiasi untuk perusahaan tersebut.

Setiap perusahaan tentu mempunyai faktor-faktor kesulitan dalam menjalankan promosinya. Dalam hal ini sejalan dengan yang telah dikemukakan oleh Kotler \& Keller bahwa pemasaran menjadi kunci utama dalam menjalankan bisnis. Place merupakan komponen terpenting dalam pemasaran seperti yang telah disampaikan oleh informan bahwa konsumen yang akan membeli kopi secara online pasti akan memilih cabang dengan radius yang terdekat dengan posisinya. Ini merupakan bagian terpenting yang harus diperhatikan dalam membuka usaha.

Gambar 1. Logo Kopi Lain Hati

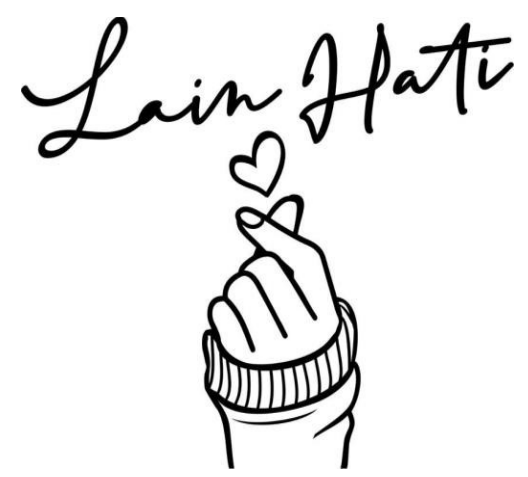

Sumber:Instagram@kopilainhati.sukasari 
Gambar 2. Struktur Organisasi Kopi Lain Hati Sukasari Bogor

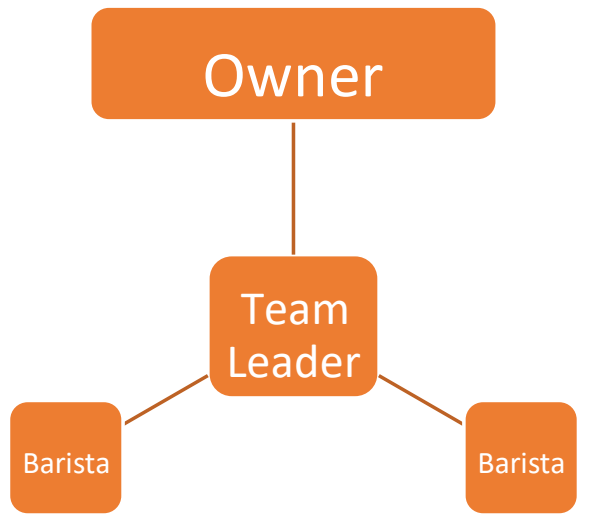

Sumber: Dokumentasi Perusahaan

Apa yang membedakan kopi Lain Hati dengan merek lainnya adalah banyaknya keunikan nama di setiap menu kopinya. Nama-nama tersebut diambil dari bahasa-bahasa kekinian sebagai dasar utama yang menjadikan kopi ini dapat diingat oleh masyarakat melalui nama-nama kopinya.

\section{Simpulan}

Berdasarkan hasil penjelasan diatas, maka kesimpulan dalam penelitian ini adalah sebagai berikut:

1. Kopi Lain Hati memiliki konsep yang sejalan dengan Generelized Others dalam menjalankan usahanya.

2. Dalam Perencanaan Komunikasi Pemasaran di Kopi Lain Hati Sukasari Bogor ada beberapa hal yang harus diperhatikan antara lain: pemilihan merek dan peninjauan, peraturan, promosi, dan strategi pemasaran.

3. Interaksi Simbolik yang terjadi pada Kopi Lain Hati Sukasari Bogor sangat mempunyai peran penting dalam kegiatan sehari-hari di gerai kopi tersebut.

\section{Ucapan Terima Kasih}

Penelitian ini dapat diselesaikan karena mendapatkan bantuan serta dukungan dari banyak pihak. Oleh karena itu, peneliti mengucapkan banyak terima kasih yang sebesar-besarnya kepada Rheinard Suananda selaku pemilik dari Kopi Lain Hati Sukasari Bogor atas ketersediannya dalam membantu penulis menyelesaikan penelitian ini, juga peneliti sampaikan ucapan terima kasih untuk semua informan yang terlibat dalam penelitian ini.

\section{Daftar Pustaka}

Creswell, Jhon W. 2013. Research Design Qualitative, Quantitative, and Mixed Methods Approaches. Third Edition, Terjemah, Achmad Fawaid, Research Design Pendekatan Kualitatif, Kuantitatif, dan Mixed. Yogyakarta: Pustaka Pelajar. 
Alfari Josita, Muhammad Adi Pribadi: Peran Interaksi Simbolik dalam Perencanaan Komunikasi Pemasaran di Era Pandemi (Studi Kasus Kopi Lain Hati Sukasari Bogor)

J.Moleong, Lexy.2014. Metode Penelitian Kualitatif , Edisi Revisi. PT Remaja Rosdakarya, Bandung.

Kotler Philip, Keller Kevin Lane (2012). Manajemen Pemasaran Terpadu edisi 12. Jakarta: Erlangga

Percy, Larry.,Rossiter, John.2012. Strategic Advertising Management. Oxford University Press: New York

Pribadi, Muhammad Adi, Suganda, Venus \& Susanto, Eko Harry (2018). Dinamika Perusahaan Periklanan Indonesia: Studi Kasus Komunikasi dan Budaya Organisasi Dwi Sapta IMC dan Fortune Indonesia. Disertasi Universitas Padjajaran. Bandung: Universitas Padjajaran.

Richard West, Lynn H.Turner. (2008). Pengantar Teori Komunikasi: Analisis dan Aplikasi (Buku 1) (Edisi 3). Jakarta: Salemba Humanika Suananda, Rheinard. (2020, April 24). Wawancara Pribadi.

Yin, Robert K. 2014. Studi Kasus: Desain \& Metode. Rajagrafindo Persada. Jakarta 